Research Article

\title{
Physico-chemical Characterization of Hemolymph Hemagglutinin of the Marine Crab Grapsus albolineatus
}

\author{
Rathika, RK*1, Mary Mettilda Bai, $\mathrm{S}^{1}$, Vinoliya Josephine Mary, $\mathrm{J}^{1}$, Citarasu, $\mathrm{T}^{2}$ and Vargila, $\mathrm{F}^{3}$. \\ ${ }^{1}$ Department of Zoology, Holy Cross College (Autonomus), Nagercoil, \\ Affiliated to Manonmanium Sundaranar University, Tirunelveli, Tamil Nadu, India. \\ ${ }^{2}$ Center for Marine Science and Technology, Manonmanium Sundaranar University, Tirunelveli, Tamil Nadu, India. \\ ${ }^{3}$ Matt Engineering Equipments, Vadasery, Tamil Nadu, India. \\ *Corresponding author's E-mail: rathiramesh1994@gmail.com
}

Received: 16-11-2021; Revised: 24-01-2022; Accepted: 30-01-2022; Published on: 15-02-2022.

\section{ABSTRACT}

Lectins, multivalent cell-agglutinating proteins, by virtue of their exquisite sugar specificities are useful tools in widespread biomedical applications. The present investigation was carried out to study the physico-chemical characteristics of the hemolymph hemagglutinin of the marine crab Grapsus albolineatus. The specificity of agglutinin to erythrocytes, sugars, glycoproteins, $\mathrm{pH}$, temperature and the effects of divalent cations and calcium chelators was determined. A naturally occurring hemagglutinin with high HA titer of 2048 with rat erythrocytes was identified in the hemolymph of the marine crab G. albolineatus. The HA activity was stable between $\mathrm{pH} 7$ and 9 and showed thermal stability between $0^{\circ}$ and $40^{\circ} \mathrm{C}$. The hemolymph agglutinin was calcium dependent and $\mathrm{HA}$ activity was reduced when exposed to calcium chelators such as EDTA and trisodium citrate. Hemagglutination inhibition assay exhibited the strongest binding specificity towards the sugars GalNAc, GlcNAc and glycoprotein fetuin. The cross-adsorption assay revealed that the hemolymph of the marine crab Grapsus albolineatus possesses single agglutinin.

Keywords: hemagglutinin, lectin, GalNAc, GIcNAc, Grapsus albolineatus.

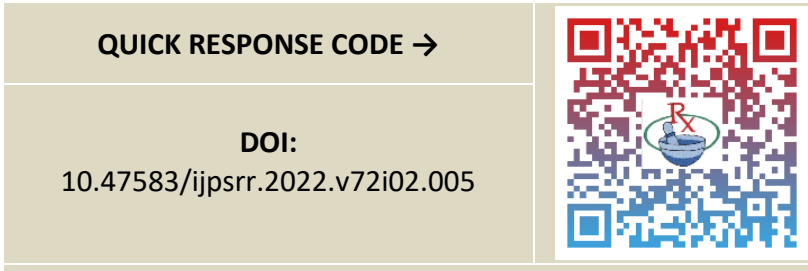

DOI link: http://dx.doi.org/10.47583/ijpsrr.2022.v72i02.005

\section{INTRODUCTION}

mmunity is the ability of organisms to distinguish self from non-self. Invertebrates which lack adaptive immune system rely on innate immunity to respond to non-self-material ${ }^{1}$. Lectins, one of the innate immune compounds play an important role as a sensor and regulator of foreign organisms ${ }^{2}$. Lectins are carbohydrate binding proteins and in invertebrates, lectin are vital means for non-self-recognition and clearance of invading microorganisms. The binding specificity of lectin therefore provides them with ability to recognize a wide variety of pathogens by recognizing the sugar found on the surface of pathogen. Lectin-carbohydrate interaction represents a ligand-receptor interaction that is universal in living organisms ${ }^{3}$.

Lectins can bind to the carbohydrate moieties on the surface of erythrocytes and agglutinate the erythrocytes, without altering the properties of the carbohydrates. Hence they are also named as hemagglutinin. Lectins exist in almost all organisms like viruses, bacteria, yeast, and protozoan and throughout all animal and plant kingdom ${ }^{4}$. Lectins are multivalent carbohydrate-binding proteins with the ability to agglutinate erythrocytes, bacteria and other normal and malignant cells displaying more than one saccharide of sufficient complementarity. Their specificity is always determined by the type of carbohydrate to which they bind 5 .

Lectins with specific carbohydrate specificity have been purified from various organisms. In invertebrates the presence of agglutinins are reported in hemolymph ${ }^{6-}$ ${ }^{13}$ Among arthropods, crustaceans are considered rich source of lectins with affinity for a variety of carbohydrates especially modified sialic acids. Lectins have been characterized from marine crabs, Scylla serrata ${ }^{14-15}$, Cancer antennarius ${ }^{16}$, blue crab, Callinectes sapidus ${ }^{17}$ and marine hair crab Erimacrus isenbeckii ${ }^{18}$. Hence an attempt was carried out to study the physico-chemical characterization of hemolymph hemagglutinin of the marine crab $G$. albolineatus.

\section{MATERIALS AND METHODS}

\section{Experimental animal}

Marine crab, Grapsus albolineatus were collected form Kadiyapatanam $\left(8.1262^{\circ} \mathrm{N}\right.$ latitude and $77.3196^{\circ} \mathrm{E}$ longitude) and Muttom (37.6428 $\mathrm{N}$ latitude and $78.3924^{\circ} \mathrm{E}$ longitude) coasts, Kanyakumari, Tamilnadu, India.

\section{Erythrocyte collection}

Erythrocytes from several mammals were collected for hemagglutination assay. Blood for this purpose was obtained by heart puncture (rat and guinea pig), venipuncture of the ear (rabbit), fore arm (human and dog), neck (buffalo and ox) and from the slaughter house 
(pig, cow and goat). Erythrocytes were collected directly in modified Alsevier's medium containing sodium citrate (30 $\mathrm{mM}, \mathrm{pH}$ 7.1), sodium chloride (77 mM), glucose (114 mM), neomycin sulfate $(100 \mathrm{mg} / \mathrm{ml})$ and chloramphenicol (330 $\mathrm{mg} / \mathrm{ml})$. Erythrocytes were suspended and washed three times with ten volumes of Tris-Buffered saline (TBS), $\mathrm{pH} 7.5$ and resuspended in the same as $1.5 \%$ suspension.

\section{Hemagglutination assay}

Hemagglutination assays were carried out as described by Ravindranath and Paulson (1987) ${ }^{19}$ to find out the presence of hemagglutinin and to know the erythrocyte specificity.

\section{pH and thermal stability}

$\mathrm{pH}$ and thermal dependence of agglutinin was measured by pre-incubating the hemolymph at specific $\mathrm{pH}(5.5-11.5)$ and temperature $\left(0^{\circ} \mathrm{C}-100^{\circ} \mathrm{C}\right)$ for 1 hour before adding erythrocyte suspension for hemagglutination assay.

\section{Cations and EDTA treatment}

To study divalent cations $\left(\mathrm{Ca}^{2+}, \mathrm{Mg}^{2+}\right.$ and $\left.\mathrm{Mn}^{2+}\right)$ dependence of Hemagglutinin, HA assays were performed in TBS ( $\mathrm{pH} 7.5)$ without and with these ions at varying concentrations. To study the effect of calcium chelators (EDTA and trisodium citrate) on the agglutinin, the hemolymph was pre incubated at different concentrations (0.01 to $100 \mathrm{mM}$ ) of EDTA and trisodium citrate for 1 hour before adding erythrocyte suspension for HA assay.

\section{Hemagglutination Inhibition Assay}

The Hemagglutination inhibition (HAI) assay was carried out with known concentration of glycoproteins and sugars by following the procedure of Ravindranath et al. $(1985)^{20}$ to know the carbohydrate specificity of the agglutinin.

\section{Cross adsorption assay}

To test whether the hemolymph contains single or multiple agglutinin, the cross-adsorption assays were carried out following the method of Hall and Rowlands $(1974)^{16}$ and Mercy and Ravindranath (1992) ${ }^{21}$.

\section{RESULTS AND DISCUSSION}

\section{Hemagglutination assay}

The presence of naturally occurring hemagglutinin in the serum of $G$. albolineatus was detected with a panel of 12 mammalian erythrocytes (Table 1 ). The agglutinin of $G$. albolineatus agglutinated rat erythrocytes with a great affinity (HA titer $=2048$ ) followed by goat $=$ mice $>$ rabbit $=$ buffalo = pig = human $B=$ human $O$. Human $A$, cow, dog and ox erythrocytes were not agglutinated by the serum agglutinin. It was observed that there was a marked difference in their hemagglutinating efficiency and the type of erythrocytes agglutinated. This suggests that the receptor determinants preferentially recognized by the hemolymph agglutinin are either abundant or more accessible on rat erythrocytes than other erythrocyte type tested. The binding specificity of the agglutinin are reflected and manifested in its preferential agglutination of erythrocytes.

Table 1: Hemagglutination titer of hemolymph of $G$. albolineatus against different mammalian erythrocytes

\begin{tabular}{|c|c|}
\hline Erythrocytes $(\mathbf{n = 1 0})$ & HA titer \\
\hline Rat & $\mathbf{2 0 4 8}$ \\
\hline Goat & 16 \\
\hline Mice & 16 \\
\hline Rabbit & 2 \\
\hline Buffalo & 2 \\
\hline Pig & 2 \\
\hline Human B & 2 \\
\hline Human O & 2 \\
\hline Human A & 0 \\
\hline Cow & 0 \\
\hline Dog & 0 \\
\hline Ox & 0 \\
\hline
\end{tabular}

$\mathrm{n}=$ number of crabs tested

\section{pH and thermal stability}

The hemagglutinin of the hemolymph of G. albolineatus was noted to be stable from $\mathrm{pH} 7$ to 9 (Table 2). $\mathrm{pH}$ below 7 and above 9 gradually reduced the hemagglutinating activity. This may be due to the dissociation of the binding sites of the agglutinin when there is a decrease or an increase in $\mathrm{pH}$ which in turn may suppress or accelerate the hemagglutination activity. The hemagglutination activity was maximum between $0-40^{\circ} \mathrm{C}$ suggesting it was an optimum temperature and further increase reduced the activity. Total loss of $\mathrm{HA}$ activity was observed at $80^{\circ} \mathrm{C}$. The loss of hemagglutinating activity with increasing temperature is evidently due to heat induced denaturation of lectin ${ }^{22}$.

Table 2: Hemagglutination titer of the hemolymph of the marine crab $G$. albolineatus in relation to $\mathrm{pH}$ and temperature

\begin{tabular}{|c|c|c|c|}
\hline $\mathbf{p H}(\mathbf{n = 1 0 )}$ & HA titer & $\begin{array}{c}\text { Temperature }{ }^{\circ} \mathbf{C} \\
(\mathbf{n}=\mathbf{1 0})\end{array}$ & HA titer \\
\hline 5 & 256 & 0 & 2048 \\
\hline 5.5 & 512 & 10 & 2048 \\
\hline 6 & 512 & 20 & 2048 \\
\hline 6.5 & 512 & 30 & 2048 \\
\hline 7 & 2048 & 40 & 2048 \\
\hline 7.5 & 2048 & 50 & 1024 \\
\hline 8 & 2048 & 60 & 512 \\
\hline 9.5 & 2048 & 70 & 128 \\
\hline 10 & 2048 & 80 & 0 \\
\hline 10.5 & 1024 & 90 & 0 \\
\hline 11 & 512 & 100 & 0 \\
\hline
\end{tabular}

$\mathrm{n}=$ Number of crabs tested 


\section{Effect of divalent cations and calcium chelators on HA}

HA titer value was altered with the different concentrations of divalent cations like $\mathrm{Ca}^{2+}, \mathrm{Mg}^{2+}$ and $\mathrm{Mn}^{2+}$ (Table 3). $10 \mathrm{mM}$ concentration of $\mathrm{Ca}^{2+}, \mathrm{Mg}^{2+}$ and $\mathrm{Mn}^{2+}$ was found to be the optimum concentration. Very low and high concentration of divalent cations tremendously decreased the HA activity. This confirms that divalent cations are significant in stabilizing the primary structure of hemagglutinins ${ }^{23-26}$.

Calcium chelator EDTA showed a different action towards the HA activity (Table 4). At the concentration from 0.01 to $1 \mathrm{mM}$ the HA activity increased to one fold and at the concentration of $10 \mathrm{mM}$ there was a sudden reduction in HA activity after which the HA activity was completely lost. G. albolineatus lectin was reversibly sensitive to EDTA. Most of the agglutinins/lectins investigated in crustaceans are known to be dependent upon divalent cations especially calcium. Usually, calcium and divalent chelators are sensitive in a reversible or irreversible manner $27-28$.
Table 3: Effect of cations on the hemagglutinating activity of the hemolymph of the marine crab G. albolineatus

\begin{tabular}{|c|c|c|c|}
\hline $\begin{array}{c}\text { Cations concentration } \\
\text { in } \mathbf{~ m M ~ ( n = 1 0 ) ~}\end{array}$ & \multicolumn{3}{|c|}{$\mathbf{H A}$ titer } \\
\hline 0 & 1024 & 1024 & 1024 \\
\hline 0.01 & 1024 & 1024 & 1024 \\
\hline 0.1 & 1024 & 1024 & 1024 \\
\hline 1 & 1024 & 1024 & 1024 \\
\hline 10 & 2048 & 2048 & 2048 \\
\hline 20 & 1024 & 1024 & 1024 \\
\hline 30 & 1024 & 1024 & 512 \\
\hline 40 & 1024 & 512 & 512 \\
\hline 50 & 512 & 256 & 128 \\
\hline 100 & 256 & 128 & 128 \\
\hline
\end{tabular}

$\mathrm{n}=$ Number of crabs tested

Table 4: Effect of calcium chelators on the hemagglutinating activity of the naturally occurring agglutinin in the hemolymph of the marine crab $G$. albolineatus

\begin{tabular}{|c|c|c|c|}
\hline \multirow{2}{*}{ Concentration in $\mathbf{m M}(\mathbf{n = 1 0})$} & \multicolumn{3}{|c|}{ HA titer } \\
\hline 0 & \multicolumn{2}{|c|}{ EDTA } & Trisodium citrate \\
\hline 0.01 & Disodium & Tetrasodium & 1024 \\
\hline 0.1 & 1024 & 1024 & 1024 \\
\hline 1 & 2048 & 2048 & 1024 \\
\hline 10 & 2048 & 2048 & 1024 \\
\hline 20 & 2048 & 2048 & 2048 \\
\hline 30 & 512 & 2048 & 1024 \\
\hline 50 & 0 & 512 & 256 \\
\hline 100 & 0 & 512 & 128 \\
\hline & 0 & 256 & 0 \\
\hline
\end{tabular}

$\mathrm{n}=$ Number of crabs tested

\section{Hemagglutination inhibition assay}

Sugar binding specificity of hemolymph agglutinin of $G$. albolineatus was examined by hemagglutination inhibition tests using carbohydrates and glycoproteins. Agglutinability was inhibited by sugars like N-acetyl-Dgalactosamine and N-acetyl-D-glucosamine (Table 5). GalNAc and GIcNAc contain the acetyl group, thereby demonstrating that an acetyl group was essential for agglutinin-ligand interaction. The binding determinants of the agglutinin were further confirmed by the hemagglutination inhibition test (HAl) using glycoprotein. Agglutination by hemolymph was inhibited by all glycoproteins tested. Fetuin strongly inhibited the hemolymph agglutinin (Table 6). The different pattern of inhibition of hemagglutination suggests the presence of lectin in the hemolymph of the tested crab. Fetuin has NeuGc as the sialic acid moiety. The glycoproteins differ not only in their sialic acid content but also with respect to the distribution of the carbohydrate chains and their linkages to protein. The highly agglutinating rat erythrocytes contain NeuGc and NeuAc. The glycoprotein fetuin contain NeuGc and the sugar GluNAc contains NeuAc. Also N-acetyl-D-Glucosamine is a precursor of $\mathrm{N}$ acetyl-D-neuraminic acid (NeuAc). This proved that the marine crab G. albolineatus is specific for acetyl/glycolyl neuraminic acid. 
Table 5: Hemagglutination inhibition of the hemolymph agglutinin of the marine crab G. albolineatus by sugars

\begin{tabular}{|c|c|c|c|}
\hline Sugars $(\mathbf{n = 5})$ & HAl titer & $\begin{array}{c}\text { Minimum concentration } \\
\text { required }(\mathbf{m M} \mathbf{)}\end{array}$ & $\begin{array}{c}\text { Relative inhibitory } \\
\text { potency (\%) }\end{array}$ \\
\hline Glucoronic acid & 4 & 25 & 6.25 \\
\hline D-galactosamine & 4 & 25 & 6.25 \\
\hline O-glucose-G-phosphate & 4 & 25 & 6.25 \\
\hline N-acetyl neuraminic acid & 4 & 25 & 6.25 \\
\hline$\alpha$ - lactose & 8 & 12.5 & 12.5 \\
\hline Trehalose & 8 & 12.5 & 12.5 \\
\hline D-mannosamine & 8 & 12.5 & 12.5 \\
\hline N-acetyl-D-glucosamine & 64 & 1.56 & 100 \\
\hline N-acetyl-D-galactosamine & 64 & 1.56 & 100 \\
\hline n= Number of crabs tested & & & \\
\hline
\end{tabular}

Table 6: Hemagglutination inhibition of the hemolymph agglutinin of the marine crab G. albolineatus by glycoproteins

\begin{tabular}{|c|c|c|c|}
\hline Glycoprotein $(\mathbf{n = 5})$ & HAl titer & $\begin{array}{c}\text { Minimum concentration } \\
\text { required for inhibition }(\boldsymbol{\mu g} / \mathbf{m l})\end{array}$ & Relative inhibitory potency (\%) \\
\hline PSM & 2 & 2500 & 6.25 \\
\hline BSM & 2 & 2500 & 6.25 \\
\hline Transferrin & 2 & 2500 & 6.25 \\
\hline Apotransferrin & 4 & 1250 & 12.5 \\
\hline Thyroglobulin & 8 & 625 & 25 \\
\hline Lactoferrin & 16 & 312.5 & 50 \\
\hline Fetuin & 32 & 62.5 & 100 \\
\hline
\end{tabular}

$\mathrm{n}=$ Number of crabs tested

\section{Cross adsorption assay}

Results of cross adsorption test showed the presence of single agglutinin in the hemolymph of the experimental crab (Table 7). In cross adsorption tests each erythrocyte type was found to completely adsorb agglutinating activity for other erythrocyte types. The results indicated that when the agglutinin was adsorbed to a particular erythrocyte species it failed to agglutinate erythrocyte of the same and other species. It evidenced the presence of only one agglutinin/lectin in the hemolymph of the experimental crab. Noguchi $(1903)^{29}$ reported that activity to one type of erythrocytes can be adsorbed by that type of erythrocytes, leaving residual agglutinating activity to other type of erythrocytes.

Table 7: Hemolymph hemagglutinin of the marine crab, $G$. albolineatus after adsorption with different erythrocytes

\begin{tabular}{|c|c|c|c|}
\hline $\begin{array}{c}\text { Erythrocytes } \\
\text { tested }\end{array}$ & Rat & Goat & Mice \\
\hline None & 2048 & 16 & 16 \\
\hline Rat & 0 & 0 & $4(0)$ \\
\hline Goat & 0 & 0 & 0 \\
\hline Mice & $4(0)$ & 0 & $4(0)$ \\
\hline
\end{tabular}

Values in parenthesis refer to $\mathrm{HA}$ titer value after successive adsorption

\section{CONCLUSION}

The hemolymph agglutinin of G. albolineatus preferentially binds to rat erythrocytes and the agglutinin exhibits maximum activity at $\mathrm{pH}$ 7-9 and temperature $0-40^{\circ} \mathrm{C}$. Hemolymph agglutinin was $\mathrm{Ca}^{2+}$ dependent and sensitive to EDTA. The sugar GalNAc and GluNAc, glycoprotein fetuin and lactoferrin inhibits hemagglutinability. Single agglutinin was present in the hemolymph of $G$. albolineatus. This study furnished all the information required for the purification of agglutinin by affinity chromatography. If purified, it could be added in the biomedically important lectin repository.

\section{REFERENCES}

1. Fujiyoshi $S$, Tateno $H$, Watsuji $T$, Yamaguchi $H$, Fukushima D, Mino S, Sugimura M, Sawabe T, Takai K, Sawayama S, Nakagawa S. Effects of hemagglutination activity in the serum of deep-sea vent endemic crab, Shinkaia crosnieri, on non-symbiotic and symbiotic bacteria. Microbes and Environments 2015; 30: 228-234.

2. Marques MRF, Barracco MA, Lectins, as non-self - recognition factors, in crustaceans. Aquaculture 2000; 191: 23-44.

3. Bulgakov AA, Park K, Choi K, Lim H, Cho, M. Purification and characterization of a lectin isolated from the Manila clam Ruditapes philippinarum in Korea. Fish and Shellfish Immunology 2004; 16: 487-499.

4. Sharon $\mathrm{N}$, Lis $\mathrm{H}$. Lectins as cell recognition molecules. Science 1989; 246: 227-234. 
5. Barondes $\mathrm{SH}$. Lectins their multiple endogenous Cellular functions. Annual Review of Biochemistry 1981; 50:207-231.

6. Mercy PD, Ravindranath $\mathrm{MH}$. Purification and characterization of $\mathrm{N}$-glycolyl neuraminic acid specific lectin from Scylla serrata. European Journal of Biochemistry 1993; 215(3): 697-704.

7. Denis M, Mercy- Palatty PD, Renuka Bai N, Jayasuriya S. Purification and characterization of a sialic acid specific lectin from the hemolymph of the freshwater crab Paratelphusa jacquemontii. European Journal of Biochemistry 2003; 270(21): 4348-4355.

8. Devi VR, Basil Rose MR, Pallaty MD. The biological role of hemolymph lectins in Episesarma tetragonum. Invertebrate Survival Journal 2013; 10: 162-171.

9. Basil Rose MR, Ravindranth MH, Mercy PD. Physico-chemical characterization of a natural agglutinin from the hemolymph of a millipede Thyropygus descriptus. Invertebrate Survival Journal 2014; 11 : 331-336

10. Elaya Bharathi T, Vinoliya Josephine Mary J, Mary Mettilda Bai S. Partial purification and characterization of hemolymph lectin of marine crab Atergatis ocyroe by adsorption on formalinized erythrocytes. International Journal of Biology Research 2017; 2(4): 115-119.

11. Sheeja UV, Basil Rose MR. An Insight of the Naturally occurring Agglutinins in a few species of crab and characterization of the Agglutinin in the crab Travancoriana charu. International Journal of Science and Research 2018; 7(12):1386-1391.

12. Vargila F, Vinoliya J, Mettilda S, Rathika RK. Characterization of a lectin purified by bioadsorbtion method from centipede Rhysida Longipes longipes. Journal of Emerging Technology and Innovative Research 2018a; 5(6):352-358.

13. Mary Mettilda Bai S, Basil Rose MR. Purification and Characterization of hemolymph lectin of freshwater crab, Lamella lamellifrons (Alcock, 1909). Annals of Tropical medicine and public health 2020; 23(7):1174-1187.

14. Philip AO, Mullainadhan P, Chrispinus SM Donald NS. Characteristics of seruma gglutinins in marine crab Scylla serrate (Forskal) and their interaction with various bacteria species. International journal of Current Microbiology and Applied SSciences 2013; 2(10): 31-43.

15. Mercy PD, Ravindranath MH. Purification and characterization of an O-acetyl sialic acid specific lectin from a marine crab Cancer antennarius. European journal of Biochemistry 1993; 260: 88508856 .

16. Ravindranath $\mathrm{MH}, \mathrm{Higa} \mathrm{HH}, \mathrm{Cooper}$ EL, Paulson JC. Purification and characterization of an O-acetyl sialic acid-specific lectin from a marine crab Cancer antennarius. The Journal of Biological Chemistry 1985; 260(15): 8850-8856.
17. Cassels FJ, Marchalonis and Vasta GR. Heterogenoushumoral and hemocyte associated lectins with $\mathrm{N}$-acetyl aminosugar specificities from the blue crab, Callinectes sapidus (Rathbun). Comparative Biochemistry Physiology 1986; 85: 23-30.

18. Na YJ, Kim YJ, Park BT, Jung BW, Hwang KW, Kim H. A novel lectin isolated from the coelomic fluid of the sea urchin. Biochemica et Biophysica Acta 2007; 14(8): 800-803.

19. Ravindranath $\mathrm{MH}$, Paulson JC. O-acetylsialic acid-specific lectin from the crab, Cancer antennarius. Methods in Enzymology 1987; 138: 520-527.

20. Hall JL, Rowlands DT. Heterogeneity of Lobster agglutinins, purification and physiochemical characterization. Journal of Biochemistry 1974a; 13: 821-827.

21. Mercy PD, Ravindranath $\mathrm{MH}$. An agglutinin with unique specificity for $\mathrm{N}$-glycolyl sialic acid residues of thyroglobulin in the hemolymph of a marine crab, Scylla serrata (Forskal). Experientia 1992; 48(5): 498-500.

22. Quadir S, Wani IH, Rafiq S, Ganie SA, Masood A, Hanrid R. Evalutation of antimicrobial activity of a lectin isolated and purified from Indigofera heterantha. Advances in Bioscience and Biotechnology 2013; 4(12): 999-1006.

23. Finsted CL, Good RA, Litman GW. The erythrocyte agglutinin from Limulus polyphemus hemolymph: Molecular structure and biological function. Annals of the New York, Academy of Sciences 1974; 234: 170-180.

24. Acton RT, Weinheimer PT. Hemagglutinins: Primitive receptor molecules operative in invertebrate defense mechanisms. In: Contemporary topics in Immunology, IV, Cooper EL (eds.) Plenum press, New York 1974: 271-282.

25. Anderson RS, Good RA. Naturally occurring hemagglutinin in the tunicate, Halocynthia phyriformis. Biological Bulletin 1975; 148: 357-367.

26. Vazquez L, Masso F, Rosas P, Montano LF, Zenteno E. Purification and characterization of a lectin from Macrobrachium rosenbergii (Crustacea, Decapoda) hemolymph. Comparative Biochemistry and Physiology Part B: Comparative Biochemistry 1993; 105(3): 617-623.

27. Ratanapo S, Chulavatnatol M, Monodin. New sialic acid-specific lectin from black tiger prawn (Peneaus monodon). Comparative Biochemistry and physiology B Comparative Biochemistry 1990; 97(3): 515-520.

28. Nalini M, Mullainadhan $\mathrm{P}$, Arumugam M. Characterization of a natural hermagglutinin in the serum of a freshwater crab, Paratelphusa hydrodromus (Herbst). Archives of International Physiology Biochemistry and Biophysics 1994; 102: 259-264.

29. Noguchi H. On the multiplicity of the serum hemagglutinin of cold blooded animals. Zentralblatt fur Bakteriologie Mikrobiologie 1903; 34:286.

Source of Support: The author(s) received no financial support for the research, authorship, and/or publication of this article.

Conflict of Interest: The author(s) declared no potential conflicts of interest with respect to the research, authorship, and/or publication of this article.

For any question relates to this article, please reach us at: globalresearchonline@rediffmail.com

New manuscripts for publication can be submitted at: submit@globalresearchonline.net and submit_ijpsrr@rediffmail.com 